\title{
Applying Estoppel Principles in Criminal Cases
}

The solidly entrenched, though little discussed, judicial principle that the government cannot be estopped in criminal actions ${ }^{1}$ is now subject to some doubt. In Raley $v$. Ohio and Cox v. Louisianu, ", the Supreme Court reversed a number of criminal convictions because the defendants had relied upon the advice of state officials that they were acting within the law. The majority opinions made these cases out as a variation of entrapment, but the facts differed significantly from the typical entrapment situation." The officials in Raley and Cox

1. See, e.g., Carolina-V'irginia Racing Ass'n v. Cahoon, 214 F.2d 830, 832 (4th Cir. 1954); United States v. Associated Gen. Contractors of America, 238 F. Supp. 273 (E.D. La 1964), rev'd per curiam, 382 U.S. 17 (1965); Commonwealth v. Malco-Memphis Theatres, $293 \mathrm{Ky}$. 531, 169 S.W.2d 596 (1943); Western Surgical Supply Co. v. Affleck, 110 Cal. App. 2d 388, 392, 242 P.2d 929, 931-32 (Cal. 1952); 28 AM. JuR. 2d, Estoppel and W'aiver \& 126 (1966); 31 C.J.S., Estoppel \& 140(c) (1964), and cases cited therein; cf. United States v. Socony.Vacuum Oil Co., 310 U.S. 15 (1940). But see United States v. Davis, 272 F.2d 149, 153 (7th Cir. 1950), where the court denied that estoppel applies in the circumstances of that casc but specifically refrained from saying that estoppel can never apply in a criminal action. Thic usual rationale given is that "the application of estoppel against the State is particularly inappropriate in areas such as criminal prosecution, where the welfare and safety of the community are the paramount considerations." State v. Abbott, 64 N.J. 131, 133, 165 A.2d $537,543(1960)$. (The question there was one of collateral estoppel but the rationale used against equitable estoppel is the same.)

In an aside, Newman, Should Official Advice Be Reliable?-Proposals as to Estoppil and Related Doctrines in Administrative Lau', 53 Colum. L. Rev. 374 (1953) states: “. . . good faith reliance on agency rulings will probably keep a man out of jail . . . This optimism seems completely unwarranted, however, as the support Newman musters for it suggests. More accurate is the observation of Hall \& Seligman, Mistake of Law' and Mens Rea, $8 \mathrm{U}$. CHI. L. REv. 641, 677 (1941) [hereinafter cited as Hall \& Seligman] that "[T]he proposed defense is much wider than that recognized by most courts."

2. 360 U.S. 423 (1959). The appellants had relied on the privilege against self-incrimina. tion when questioned by a commission of the Ohio legislature. Despite the fact that the commission assured the appellants that they had a right to silence, the Supreme Court of Ohio affirmed their contempt convictions on the theory that a state immunity statute deprived them of the privilege. State of Ohio v. Raley, 164 Ohio St. 529, 133 N.E.2d 101 (1956). The United States Supreme Court reversed. All eight justices participating agreed as to three of the four appellants:

We hold that in the circumstances of these cases, the judgments of the Ohio Supreme Court affirming the convictions violated the Due Process Clause of the Fourteenth Amendment and must be reversed. ... After the Commission, speaking for the Statc, acted as it did, to sustain the Ohio Supreme Court's judgment would be to sanction an indefensible sort of entrapment by the State-convicting a citizen for exercising a privilege which the State had clearly told him was available to him.

360 U.S. 425-26. Four justices voted to affirm the conviction of appellant Stern since Stern had refused to answer the question, "Where do you reside, Mr. Stern?" and persisted in his refusal when directed by the commission to answer the question. Thus Stern's con. viction was affirmed by an evenly divided court. Id. at 444.

3. 379 U.S. 559 (1965). The Chief of Police of Baton Rouge "gave permission" to Cox, the leader of a demonstration involving over 2000 persons, to proceed to a point across the street from a courthouse where a group of arrested demonstrators werc bcing held. A Louisiana statute prohibited picketing "near" a courthouse. LA. REv. STAT. \$ 14.401 (Cum. Sup. 1962). Cox was convicted under the statute, but the Court reversed finding the same "active misleading," 360 U.S. at 438, that was dispositive in Raley.

4. The Supreme Court first addressed itself to the entrapment doctrine in Sorrells $v$. 
were known by the defendants to be government agents and had no design to deceive and entrap the defendants, nor did they persunde the defendants to commit the criminal acts. ${ }^{5}$ Instead, they merely gave their honest opinion that what the defendants proposed to do was not unlawful. While the entrapment doctrine rests at least in part on the need to control undesirable police practices, ${ }^{\circ}$ the Raley and Cox hold-

United States, 287 U.S. 435 (1932), and propounded a two-fold test for the defense: (1) the crime is the product of the creative activity of the government agents which defendant was induced to participate in; and (2) the defendant did not have a criminal predisposition or design. Id. at 451 . They stated that the true basis for the defense was statutory interpretation:

We are not forced by the letter to do violence to the spirit and purpose of the

statute. ... If the requirements of the highest public policy in the maintenance of the integrity of administration would preclude the chiforcenent of the statute in such circumstances as are present here, the same considerations would justify the conclusion that the case lies outside the purview of the Act and that its general viorels should not be construed to demand a proceeding at once inconsistent with that policy and abhorrent to the sense of justice.

$I d$. at 448-49. This view was followed in the latest entrapment decision by the Court. Sherman v. United States, 356 U.S. 369 (1957). But see note 6 infra.

See generally Donnelly, Judicial Control of Informants, Spies, Slool Pigeons and Pro. vocateurs, 60 YaLE L.J. 1091 (1951); Rotenberg, The Police Detection Practice of Encouragement, 49 VA. L. REv. 871 (1963); Note, Entrapment, 73 HARv. L. RE. 1333 (1960): Note, The Serpent Beguiled Me and I Did Eat, The Constitutional Status of the Entrap. ment Defense, 74 Yale L.J. 942 (1965).

5. In Sorrells and Sherman, the entrapment cases cliscussed in note 4 supra, the gov. ernment agents were involved in the practice of encouraging or inducing criminal con. duct by the defendant through undercover informers. This is in stark contrast to the facts presented in Cox and Raley where the defendants sought advice, or receised it gratuitously, from state officials as to the proper course of action to be followed in the situation presented at the time.

6. The proper rationale for the entrapment defense has been disputed. Sorrells : United States, 287 U.S. 435, 456.57 (1932) (Roberts, J.. concurring): Sherman v. United States, 356 U.S. 369, 381 (1957) (Frankfurter, J., concurring). Both concurrences held that the proper basis for the defense was the inherent power of the judiciary to protect the courts from the degradation of convicting persons who had been induced to commit illegal acts. In Sherman, Frankfurter states that this power derives from the Court's "supervisory jurisdiction over the administration of criminal justice." 356 U.S. at 381. This view implies that the purpose of the defense is control of police solicitation tactics. On balance. the concurrence's view is more reasonable than the legislative intent position adopted by the majorities. See note 4 supra. Legislative intent on the issue is problematic. The legis. lature wanted simply to prohibit certain conduct, conduct in which the defendant en. gaged. The fundamental issue has nothing to do with the defendant's culpability:

The defendant whose crime results from an entrapment is neither less reprehensible or dangerous nor more reformable or deterrable than other defendants who are properly convicted. Defendants who are aided, deceived or persunded by police officinls stand in the same moral position as those who are aided, deceived or persunded by other persons. It is the attempt to deter wrongful conduct on the part of the govern. ment that provides the justification for the defense of entrapment not the innocence of the defendant.

MODEL Penal Code \$ 2.10 at 14, Comments (Tent. Draft No. 9, 1959). This recognition that the integrity of the criminal process is at stake implies that entrapment is a defense of constitutional proportions under the due process clause. See Note, 74 YALE L.J. 942, 945 (1965), compare the language used by both groups in Sherman and Sorrells with that used in Rochin v. California, 342 U.S. 165, 169,173 (1952). Since the legitimate goal of law enforcement practices is the prevention and detection of anti-social conduct, not the solicitation, inducement or creation of anti-social acts, a "less restrictive alternative" model demonstrates the need for constitutional restraints on such police practices. See Note, 74 YaLe L.J. 942, 945-47 (1965) for a discussion of the legitimate state goal in the entrap. 
ings reflect only an elemental notion of fairness: the individual must have fair warning of what conduct the government intends to punish. ${ }^{7}$

Ordinarily, of course, a "mistake of law" is no answer to a criminal charge. ${ }^{8}$ The policies underlying the penal law are thought sufficiently serious that the citizen must be at his peril to know the law and obey it. $^{9}$ Nonetheless, the Supreme Court on numerous occasions has found constitutional objections to criminal laws which did not express the proscribed conduct with minimal clarity. ${ }^{10}$ Moreover, the long-standing

ment practice. For a comprehensive analysis of the use of the due process clause 10 protect fundamental social values by insisting on a socially useful purpose and the least intrusive methods of all state action, see Ratner, The Function of the Due Process Clause, $116 \mathrm{U}$. PA. L. REv. 1048, 1075-89 (1968). One commentator concludes that the Constitution estab. lishes three independent limitations on police entrapment practices based on self-incrimination, due process, and search and seizure. Note, 74 YALE L.J. 942, 952 (1965);

7. "Engrained in our concept of due process is the requirement of notice," Lambert v. California, 355 U.S. 225, 228 (1957). See also Wright v. Georgia, 373 U.S. 284, 293 (1963); In re Anastoplo, 366 U.S. 82,94 (1960). This requirement cannot reasonably be met when the state speaks with contradictory voices-one voice from the criminal statute at issuc and another from the law enforcement officials. See Johnson v. United Statcs, 318 U.S. $189,197(1943)$.

8. See Model Penal Code, \& 2.02(a) (Tent. Draft No. 4, 1955). But see ill., Comments 131: It should be noted that the general principle that ignorance or mistake of law is no excuse is usually greatly overstated; it has no application when the circunstances made material by the definition of the offense include a legal clement.

Some commentators have dealt with estoppel situations as part of the broader catcgory of mistake of law. See, e.g., Hall \& Seligman, supra note 1, at 675.83; Ryu \& Silving, Error Juris: $A$ Comparative Study, 24 U. CH1. L. REv. 421, 436.38 (1957); MODEL PENA. ConE $\S 2.04(3)$ (b)(iii), Comment (Tent. Draft No. 4, 1955).

9 . It is no doubt true that there are many cases in which the criminal could not have known that he was breaking the law, but to admit the cxcuse at all would be to encourage ignorance where the law-maker was determined to make men know and obey, and justice to the individual is rightly outweighed by the larger interests of the other side of the scale.

O.W. Holmes, The Common Latw 48 (1881). See p. 1054 infra.

10. The constitutional requirement of precision or clarity in statutory criminal laws proceeds from the due process notion that an individual ought to be adequately warned that sanctions will attach to conduct he might contemplate, and that such warning maly that sanctions will attach to conduct "men of common intelligence must necessarily guess not be issued in such a form that "men of common inter as to its application." Connally v. Gen. Constr. Co., 269 U.S. 385, 391 (1926). See also Giaccio v. Pennsylvania, 382 U.S. 399 (1966); Winters v. New York, 333 U.S. 507 (1948); Lanzetta v. New Jersey, 306 U.S. 45I, 453 (1939); Chatmplin Ref. Co. v. Corp. Comm. of Oklahoma, 286 U.S. 210, 243 (1932); United States v. Cohen Grocery, 255 U.S. 81, 89 (1931); Int'l Harvester Co. v. Kentucky, 234 U.S. 216 (1914); Col. lins v. Kentucky, 234 U.S. 634 (1914). Aside from the notice requirement, concern over vague critcria arises from the fear of the potential for government abuse and uncertainty of application that is afforded. See, e.g., Smith v. California, 361 U.S. 147 (1959); Watkins v. United States, 354 U.S. 178 (1957); Connally v. Gen. Constr. Co., supra at 895 . The vagueness doctrine also derives support from the concern that judicial tribunals ought to apply statutes within the bounds of construction and interpretation and not be clarged with the essentially law-making function of providing vague legislation with content. See, e.g., Cline v. Frink Dairy Co., 274 U.S. 445 (1927); Patten v. Alum. Castings Co., 105 Ohio St. 1, 136 N.E. 426 (1922). But see Nash v. United States, 229 U.S. 373 (1919). Even stricter standards of precision are applied where vagueness might result in a chilling effect on first amendment freedoms. See Keyishian v. Bd. of Regents, 385 U.S. 589 (1967); Baggett v. Bullitt, 377 U.S. 360 (1964); Cramp v. Bd. of Pub. Instruction, 368 U.\$. 278 (1961); Shelton v. Tucker, 364 U.S. 479, 488 (1960); Smith v. California, supra; Nicmotko v. Maryland, 340 U.S. 268 (1951); Thomas v. Collins, 323 U.S. 516 (1945); Herndon v. Lowry, 301 U.S. 242 (1937); Stromberg v. California, 283 U.S. 359, 369 (1931). Sce Note, The Void-for-Tagueness Doctrine in the Supreme Court, 109 U. PA. L. REv. 67 (1060). 
rule that the words or actions of its agents cannot estop the government has suffered considerable erosion. ${ }^{11}$ In its application to civil cases, courts and commentators have long attacked it, ${ }^{12}$ while in criminal cases the ex post facto clause-and its due process analog when a high court has reversed itself on a matter of statutory or constitutional interpretation ${ }^{13}$ _embodies principles similar to the estoppel doctrine.

11. See, e.g., Moser v. United States, 341 U.S. 41,46 (1951); Innited States v. Fox Latic State Bank, 366 F.2d 962 (7th Cir. 1966); Stockstrom v. Comm'r, 190 F2d 283 (D.C. Cir. 1951); United States v. Associated Gen. Contractors of Americ, 238 F. Supp. 273 (E.D. La. 1964), rev'd per curiam, 382 U.S. 17 (1965); City of Sheridan v. Montana-Dakota V'til. Co., 157 F. Supp. 664,670 (D.C. Wy. 1958); Gruber v. Major of Raritan, 39 N.J. 1, 186 A.2d 489 (1962) (extensive review of authorities); V'ogt v. Borough of Belmar. 14 X.J. 19j. 206-07 (1954); Gity of Los Angeles v. Los Angeles County, 9 Cal. 2d 624, 630-31 (1937). However, the state of the law on the application of equitable estoppel principles to governments and governmental agencies is presently very uncertain. Sec $K$. DAsts, Adus: ISTRATIVE LAW TrEATUSE $\$$ 17.01-.03 (1958). For cases supporting the view that the government cannot be estopped, see, e.g., Fed. Crop Ins. Corp. v. MIerrill, 332 US. 380.383 (19 17): Legerlotz v. Rogers, 266 F.2d 457, 459 (D.C. Cir. 1959); Rock v. United States, 279 F. Supp. 96, 101 (S.D.N.Y. 1968); United States v. Ameco Electronic Corp., 224 F. Supp. 783, 786 (E.D.N.Y. 1963).

12. See, e.g., K. Davis, Administrative Law Treatise $\$ \S 17.01-09$ (1958); Berger, Estoppel Against the Goternment, 21 U. CHI. L. Rev. 680 (1954); Manning, The Application of the Doctrine of Estoppel Against the Government in Federal Tax Cases, 30 X.C.L. REv. 356 (1952); Newman, Should Official Advice Be Reliable?-Proposals as to Estoppel and Related Doctrines in Administrative Law, 53 CoLun. L. REv. 371 (1953); Whelan \& Dunigan, Government Contracts: Apparent Authority and Estoppel, 55 GEo. L.J. 830 (1967); Comment, Estoppel Against the Govermment in California, 41 C.1t.1F. L. Rex: 340 (1956); Comment, Estoppel Against State, County, and City, 23 Wasu. L. Rev. 51 (1948). Various courts and judges have also dealt with the problem in some depth. Sce cases cited in note 11 supra. The uniform agrecment of commentators that the traditional doctrine should be discarded is matched by the judicial dissatisfaction with the ductrine demon. strated in the numerous judicial abridgments of the no-estoppel rule. See $31 \mathrm{C}$.J.S. Estoppel $\$ \$ 138-46$ (1964). Thus, governments are more likely to be cstopped when the litigation has arisen out of their "proprietary" functions rather than their "govern. mental" or "public" functions, when the government is the plaintiff rather than the defendant, when the act of the agent relied on was "authorized" rather than "unauthorized," when the question is procedural rather than substantive, when it is a subordinate government or governmental agency rather than a sovereign state or the Unitcd States, and when the government's misrepresentation is by "action" rather than "inaction."

It is apparent that the more liberal view will gain increasing acceptance. It should bc noted, however, that the demise of the traditional doctrine is not altogeduer a foregone conclusion, and the optimism of Professor Davis on this point may be somewhat premature. See, e.g., Kondo v. Katzenbach, 356 F.2d 351, 363 (1966) (J. Skclly Wright, J., dissenting). Judge Wright based his dissent on estoppel grounds and supported his position with ample precedent and scholarship. On appeal the Supreme Court reversted, sub nom. Honda v. Clark, 386 U.S. 484, 500 (1967), but rested its decision on byzantine statutory interpretation. It specifically refused to reach the estoppel issuc. In any case, the growing curtailment of the traditional doctrine does not imply that the government will uniformly be held estopped by actions that would estop a private party. Rather, uhe equities of the situation will be balanced with governmental needs kept in mind. Sec United States v. Radio Corp. of America, 358 U.S. 334 (1959); Gcorge H. Whike Constr. Co. v. United States, 140 F. Supp. 560 (Ct. Cl. 1956).

13. Bouie v. City of Columbia, 378 U.S. 347, 362 (1961). Petitioners, "sit-in" demon. strators, were convicted of refusing to leave private property after being asked to do so under a criminal statute which proscribed entry on the lands of another after notice prohibiting entry. The South Carolina Supreme Court affirmed on the basis of a subsequent decision construing the statute as applicable to the act of remaining on the premises of another after receiving notice to leave. The United States Supreme Court reversed, holding that the statute did not give the petitioners fair notice that their conduct was illegal, and that the state court's retroactive application of its new construction of the stamte 
If the Supreme Court chooses to follow the logic of Raley and Cox, it must end by replacing the no-estoppel rule in criminal prosecutions with some sort of due process-estoppel defense. The Court might contrive some basis for distinguishing and isolating the two cases: both have first amendment undertones, Raley involves a conviction for contempt of a state legislative commission-not a common occurrence-, and in Cox Justice Goldberg's majority opinion pointed out that a statute prohibiting picketing "near a courthouse" raised some questions of vagueness. ${ }^{14}$ Yet it is not easy to draw fine and narrow lines around fundamental concepts of fairness, ${ }^{15}$ and it is not likely that the Court will want to do so.

On the other hand, constructing a doctrine of criminal estoppel from the rationale of Cox and Raley is no simple task itself. These two cases may provide the precedential foundation for such a doctrine, ${ }^{10}$ but they

amounted to a denial of due process since it operated exactly like an ex post facto law. The underlying equitable rationale is similar to criminal estoppel. However, it is uIIrealistic to think that the petitioners were relying on the wording of the statute, particularly since both petitioners expressed a willingness to be arrested and the expectation that they would be. Id. at 367 (Black, J., dissenting). Also, it seems safe to say that in 1960 a black person about to sit-in at a lunch counter in Columbia, South Carolina, could reasonably expect to be arrested and convicted of some criminal violation. However, to make reliance the only relevant question is to ignore half the problem-the conduct of the state. The majority's recognition of the functional equivalency of such retroactive application to ex post facto laws adequately characterizes this type of judicial cleviation from the rule of law.

Also note Justice Brennan's statement that the petitioners' conduct was not "improper or immoral." Id. at 362. In this connection, see Hall \& Seligman, supra note 1.

See also James v. United States, 366 U.S. 213 (1961). James had been convicted of "wil. fully and knowingly" failing to pay income tax on embezzled funds, and based his defense on Comm'r v. Wilcox, 327 U.S. 404 (1946), which held that embezzled funds were not taxable income. The Supreme Court overruled Wilcox, yet reversed James' conviction. Three justices rested on the ground that since his actions took place while I'ilcox was still valid, "wilfulness" couldn't be shown, and three others on the gounds that Ifilcox was right when decided. In addition, Justices Harlan and Frankfurter (who had agreed on the overruling of Wilcox) voted to remand the case for a new trial in which the gov. ernment would have to prove that James' failure to pay income taxes was wilful, i.e., that he did not rely on Wilcox. On the prospective overruling issue generally, see Note, Pro. spective Overruling and Retronctive Application in the Federal Courts, 71 Yat.1 1.J. 907. 923-27 (1962). See also Desist v. United States, 37 L.W. 4225 (1969); Linkletter v. Walker, 381 U.S. 618 (1965).

14. Cox v. Louisiana, 379 U.S. 559, 568 (1965). The majority admitted that there was "some lack of specificity in a word such as "near'." However, the Court circumvented this problem, saying that though the statute was not unconstitutionally vague, it required and anticipated "a degree of on-the-spot administrative interpretation by officials." $I d$. This analysis has been found unpersuasive by at least one commentator. Note. The Supreme: Court, 196.1 Term, 79 Harv. L. Rev. 105, 154 (1965). See note 10 supra.

15. On the fundamental nature of due process adjuclication and the broad scope of the Court's power under that clause, see Ratner, The Function of the Due Process Clause, 116 U. PA. L. Rev. 1048 (1968).

16. The opinions in Raley v. Ohio, 360 U.S. 423 (1959), managed to ignore totally the estoppel implications of that decision. Some cursory mention of the fundancutal nature of the issue can be found in Cox. Mr. Justice Goldberg stated for the majority:

Nor does this limited administrative regulation of traffic which the Court has con.

sistently recognized as necessary and permissible, constitute a waiver of law which is

beyond the power of the police. Obviously telling demonstrators how far from the 
hardly suggest the finished analytic structure. Most importantly, the opinions fail to take account of the basic policy reasons for the noestoppel rule: the doctrine of separation of powers and the fictive presumption that every citizen knows the criminal law. However much the rule's urgency has been exaggerated, the policy underlying it is by no means unimportant and, eventually, must help shape any emerging theory of criminal estoppel.

I.

Separation of Powers. ${ }^{17}$ - The interests embodied in the criminal law are public interests of the greatest weight. No official or agency of

courthouse steps is "near" the courthouse for purposes of a permissible peaceful demonstration is a far cry from allowing one to commit, for cxample, murder, or robbery.

379 U.S. at 569.

In dissent, Mr. Justice Black stated categorically that "a police chief cannol authorize violations of his State's criminal laws." Id. at 582. However, the cases cited in support of this broad statement demonstrate that support for Black's position is as difficult to inuster as its opposite. All three are antitrust cases; and only Socony is a criminal prosecution: United States v. Philadelphia Nat'l Bank, 374 U.S. 321, 350-52 (1963); California v. Federal Power Comm'n, 369 U.S. 482, 484-85 (1962); United States v. Socony-Vacuum Oil Co., 310 U.S. 150, 225-27 (1940).

In Socony the defendants had offered to prove the encouragement, cooperation and acquiescence of the Federal Petroleum Administration in the buying programs the defendants had inaugurated in order to stabilize the price of refined gas. The trial court rejected the offer and the Supreme Court affirmed. The Court noted that the National Industrial Recovery Act set up a mechanism for securing immunity for such programs from the Sherman Act. The defendants eschewed that mechanism while it was operative, and the scheme continued after the expiration of the NIRA. It is reasonable to read the case as one in which the agency had "alerted defendants that their conduct would be considered unlawful unless formal approval were obtained." (as the district court did in United States v. Associated Gen. Contractors of America, 298 F. Supp. 273, 283 (E.D. La. 1965)), although the Court in Socony specifically refused to rest on this ground. The Supreme Court reversed per curiam in Associated General, 382 US. 17 (1965). citing Socony and Times-Picayune Pub. Co. v. United States, 345 U.S. 594, 623-24 (1953). ("DoubIless, long-tolerated tade arrangements acquire no vested immunity under the sherman Act; no prescriptive rights accrue to the prosecutor"s delav:")

The decisions in Cox and Raley certainly curtail the scope of the language in Socony relied on in the per curiam reversal. If the Socony principle is to be considered viable today, it must be due to the peculiar characteristics of the antitrust field or the limited reading of the case that the district judge gave it in Associnled General.

Certainly Associated General is not the vehicle to reinstate the no-estoppel doctrine even in the antitrust field. The district court used estoppel language, but lie decision is erroneous on any basis and should be deemed a sport. The judge brought the estoppel issue up sua sponte based on a single document submitted by the government for another purpose. The question the government presented on appeal vas whether the government is estopped from prosecuting someone criminally solely because, after previously investigating the activity, it did not institute civil or criminal suit thercon. This is a fair statement of the record. The government had investigated the Association ten years prior to this action and issued no statement or indictment. The Association argued in its brief that the case was covered by Cox and that the appeal should bc dismissed for want of a substantial federal question. Nothing in Cox or this Note covers such a case since there was no inducement, no widespread nonenforcement, no advice, and probably no reliance. The case deserved the summary reversal the Court gave it. See Case Noic, 196 Duks: L.J. 619.

17. The traditional formulation of the doctrine of separation of poisers dictates that 
government has the authority to waive the public interest, ${ }^{18}$ and so none-save the legislature-can define the limits of the criminal law. A defense of criminal estoppel would in effect permit the individual official to alter or suspend the statutory penal law simply by mis. interpreting it. $^{19}$

Justifying the rule against estopping the government in terms of separation of powers, however, is only a formal expression of the belief that the criminal law is too serious a matter to allow law enforcement officials to make mistakes as to what it covers. If the individual is unsure where the boundary of lawful conduct lies, he should "steer wide of the unlawful zone" rather than seek official advice as to how far he might legally go. This makes a great deal of sense where the prohibited conduct threatens grave injury to persons or property or a serious disruption of the economy, but the no-estoppel rule has traditionally been applied without regard to the gravity of the offense and its probable consequences. ${ }^{20}$ The criminal law has become ex-

the legislative branch retain exclusive power to make the law. "All legislative powers herein granted shall be vested in a Congress of the United States, which slatl consist of a Senate and House of Representatives." U.S. CoNst. art. I. See, e.g., Schechter Poultry Corp. v. United States, 295 U.S. 495, 529.42 (1935); Panama Refining Co. v. Ryan, 298 U.S. 388 (1935); Youngstown Sheet \& Tube Co. v. Sawyer, 343 U.S. 579 (1952).

However, numerous institutional compromises have been grafted onto this moclel. Sece generally C. Black, Perspectives in Constitutional Law 56.64 (1963); A. Bickit, THE Least Dangerous Branch, 159-61 (1962); L. JafFe, Judicial Control of Administrative Action 28-86 (1965); 1 K. Davis, Administrative LAw Treatise \$ $2.01 \cdot .16$ (1958); Jaffe, An Essay on Delegation of Legislative Power: II, 47 Colun. L. REv. (19.17).

18. See Cox v. Louisiana, 379 U.S. 559, 582 (1965) (Black, J., dissenting). See note 16 supra. See generally articles cited note 12 supra.

19. As the law now stands, police and other law enforcement officers have not been delegated discretion not to invoke the criminal process for violations within the "full enforcement area." J. Goldstein, Police Discretion Not to Invoke the Criminal Process: Low Visibility Decisions in the Administration of Criminal Juslice, 69 YALE L.J. E13, $\mathbf{5 7 7 - 8 0}(1960)$ [hereinafter cited as J. Goldstein]. For a graphic illustration of the level of actual enforcement, see $i d$. at 563; The Challenge of Crime in a Free Societr, $A$ Rz: PORT by the President's Comilssion on LAw Enforcement and Adninistration ol Justice 8-9 [hereinafter cited as CHAl.LENGE].

20. Despite the strength of the no-estoppel rule, scattered state cases indicate that the principle of criminal estoppel is gaining some acceptance. See, e.g., Pcople v. Furguson, 134 Cal. App. 41, 24 P.2d 965 (1933). The court reversed conviction for violation of state securities statute for failure to get a permit to sell certain interests in a land development scheme. The trial court had rejected the defendant's offer to prove that lic laal been in doubt as to whether the scheme was covered by the statute and had received a ruling from the corporations commissioner that the land interests were not "securities" and thus no permit was needed. But see Western Surgical Supply Co. v. Afleck, 110 Cal. App. 2d 388, 242 P.2d 929 (1952). See also Market Street Ry. Co. v. State Bd. of Equalization, 137 Cal. App. 2d 87, 290 P.2d 20 (1955); State v. Ragland, 4 Conn. Cir. 424, 233 A.2d 698 (1967) (discussed at note 73 infra; Pcople v. Donovan, 27 App. Div. 2d 957, 279 N.Y.S.2d 404 (1967) (discussed at note 80 infra); People v. Markowitz, 18 N.Y.2d 953, 223 N.E.2d 572, 277 N.X.S.2d 149 (1966) (defendant made various attempts to get a peddler's licensc to sell scorecards at ballpark, but was told by licensing officials that it wasn't nccessary; later he was convicted of unlicensed peddling, but the New York Court of Appeals re. versed per curiam on the basis of Cox); Commonwealth v. Wilson, 158 Pa. Super. 198, 44 A.2d 520 (1945) (where the local practice had been to issue two subpocnas for attendance of Commonwealth witnesses, one for the grand jury and anothet for the trial, atl 
tensively used as an instrument of social control with a complex, sometimes labyrinthian administrative structure. Where an individual has relied upon the enforcement agency's interpretation of a highly technical law, ${ }^{21}$ or obeyed the reasonable order of someone with apparent authority to give it, 22 allowing the government to disclaim the action of its agent seems not only unjust, but unnecessary to the proper functioning of the criminal process and to any rational theory of the allocation of power between different branches of government.

The Presumption of Knowledge of the Law.-Courts refusing to apply estoppel against the government in civil cases often state that the citizen is charged with knowledge of the statutes and regulations relevant to the transaction..$^{23}$ In the criminal area, the common law enshrined this notion in the rule that ignorance of the law is no excuse for breaking it. ${ }^{24}$ Though the presumption was admittedly a

individual had a right to rely on the custom; though the defendant was unable to appear at the grand jury due to illness, and it was not Iegally necessary to send two subpoenas, the judgment of conviction for failure to obey the one subpoena was reversed); Pcople $v$. the judgmen, I4 N.Y.2d 901, 200 N.E.2d 779, 252 N.Y.S.2d 96 (190t) (memorandum decision). conviction rev'd, 50 Mrisc. 2d 751, 271 N.Y.S.2d 447 (Sup. Ct. 1966) (discussed at note 106 infra).

21. See People v. Ferguson, 134 Cal. App. 41, 24 P.d 965 (1933).

22. See State v. Ragland, 4 Conn. Cir. 424,233 A.2d 698 (1967).

23. See, e.g., Fed'l Crop Ins. Corp. v. Merrill, 332 U.S. 380 (1947). The plaintiff applied for a wheat crop insurance policy from the FCIC through the county committee, disclosing to them that part of the crop vas reseeded winter wheat. The branch office of FCIC approved the policy on the county committee's recommendation. When the plaintiff tried to recover under the policy, the FCIC refused to pay, based on a riheat Crop Insurance Regulation that precluded insurance for reseeded wheat. The county committee had misled plaintiff to believe the entire crop was insurable, and plaintiff had no knowledge of the regulation. The Supreme Court reversed a jury verdict for the plaintiff sajing that private parties are bound to know the law regulating government agents.

It is more reasonable to charge the citizen with knowledge of the law in a criminal case since the relevant law proscribes the conduct by the individual rather than regulating the power distribution within the government. See note I6 stpra, especially United States v. Socony-Vacuum Oil Co., 310 U.S. 150 (1940).

24. See note 9 supra. See generally Hall \& Seligman, supra note 1 .

Austin felt that the question of whether the defendant was accually ignorant of the law was so difficult to solve that the adjudication of the issue would be impractical or impossible. J. AustiN, JuRISPRtDENCE $\S 699$, at 342 (Campbell ed. 1875). As Holmes pointed out, this rationale for the rule is entirely insufficient:

[The presumption] has accordingly been defended by Austin and others, on the ground of difficulty of proof. If justice requires the fact to be ascertained, the difficulty of doing so is no ground for refusing to try. ... [N]ow that partics an testify, it may be doubted whether a man's knowledge of the law is any harder to investigate than many questions which are gone into. The difficulty, such as it is, would be met by throwing the burden of proving ignorance on the law-breaker.

O. W. Holmes, The Conmon Law 48 (188I).

Objections to this position are no more persuasive than Austin's original statement. See, e.g., Hall \& Seligman, supra note 1, at 647-48. Sec, e.g., Lambert v. Colifornia, 355 U.S. $225(1957)$, where the Court eschewed the common law principle that ignorance of the law will not excuse, and held that an ex-convict who failed to register as a convicted person under an ordinance requiring registration could not be held criminally liable for the failure absent actual notice of the ordinance. Due process requires notice in these 
fiction at common law, the diversity of American society and the explosion of statutory crimes has divorced the fiction from reality entirely.

In fact, the criminal process has not for some time been the simple mechanism which the no-estoppel rule presupposes. Legislatures continually pass criminal statutes that require interpretation ${ }^{25}$ and outright policy-making by administrative officials. Separate agencies may share responsibility for enforcing the same body of law. Even the police, working with many broadly-framed laws and limited resources, make refinements in the law that the legislature may not have intended. ${ }^{2 \pi}$ An individual, confronted with the practices and views of the enforcement agency, has little means of discovering whether the prosecutor-much less the legislature-knows or agrees with how the law is being administered. In light of such state-sponsored confusion, government insistence that the citizen should know the true state of the law is at best unreasonable. ${ }^{28}$

Reasons which might justify the no-estoppel rule in some cases, therefore, do not apply in many others, while the reason for an estoppel

circumstances because the "conduct" was wholly passive and the defendant had no knowledge of any wrongdoing.

The presumption is also overcome in other situations. Where the Court determines there was a lack of mens rea, there is no conviction. See note 77 infra. Similarly, the legis. lature may require more than the presumption or a general intent to do the acts, e.g. by requiring a specific intent to violate the law, that the acts be done "wilfully." See James v. United States, 366 U.S. 213, 221 (1961); United States v. Murdock, 290 U.S. 989 (1933).

25. The statute involved in Cox v. Louisiana, 379 U.S. 559 (1965), is an example. The classic example is the normal breach of the peace statute. See H. Goldstein, Police Dis. cretion: The Ideal Versus the Real, 23 PUBL. ADMIN. Rev. 140, 142-43 (1967); Remington \& Rosenblum, The Criminal Law and the Legislative Process, 1960 U. It.. L. FonUM 481, $485-93$ (1960).

26. See J. Goldstein, supra note 19, at 560-62; H. Goldstein, supra note 25, at 142-43.

27. These decisions have a wide impact on the attitudes of citizens toward the criminal law, law enforcement, and government generally. See CHullence, supra note 19, at 91.95, 99-101; Hall, Police and Law in a Democratic Sociely, 28 IND. L.]. 133, 144 (1953); W. LaFave, Arrest: The Decision to Take a Suspect into Custody 89.91, 148.49, 155.56 n.16 (1965) [hereinafter cited as LAFAve]; Williams, Turning a Blind Eye, 1954 Crum. L. REv. 271.

These distinctions or refinements may be rational ones based on sound policy determina. tions. But see, e.g., J. Goldstein, supra note 19, at 553, particularly n.17; Yick Wo v. Hopkins, 118 U.S. 356; Pcople v. Utica Daw's Drug Co., 16 App. Div. 2d 12, 225 N.Y.S.2d 128 (1962); and note 108 infra. But even rational enforcement distinctions may operate against the goals of the criminal process or the legislative will. See J. Goldstein, supra note 19 , at $562,567-73,576-77,582-86$.

28. If the main basis for the presumption is the state's need "to make men know and obey," the fact that the executive arm of the state has interposed a different stanclard for obedience, a standard including the threat of immediate enforcement as well as the power to grant effective immunity, vitiates the rationale for the presumption. See Hall \& Selig. man, supra note 1, at 649; MOdel PeNal CODE, $\S 2.04(3)$ (b) and comments, at 17.18, 198.99 (Tent. Draft No. 4, 1955). See also Ryu \& Silving, Error Juris: A Comparative Sludy, 21 U. CHI. L. REv. 421, 496-38 (1957). 
defense applies in all.99 Moreover, recognition of a criminal estoppel defense would focus attention on interstitial law-making by enforcement agencies, ${ }^{30}$ providing the legislature a more realistic view of the criminal process ${ }^{31}$ and enabling different branches of the government to better coordinate their roles in administering the criminal law. The question, then, becomes not whether the courts should accept a defense of estoppel, but how far it should extend-in short, a question of what kind of reliance on what kind of official mis-representation should estop the state from prosecuting a person for what kind offense.

II.

Because a plea of estoppel would constitute a special excuse for a criminal act and would often involve facts peculiarly within the de-

29. The suggestion for an estoppel defense contained in this Note is not altogether original, but it does go considerably bejond earlier proposals. See Comment, Fsioppel Against the Government in California, 44 CALIF. L. REv. 340, 342-44, 352-53 (1956), for a section of a proposed statute on estoppel that would deal with a limited number of the situations discussed herein. See also People v. Donoran, 53 Misc. 2d 687, 279 X.Y.S.2d 40-1 (Spec. Sess., Westchester 1967); Case Note, 81 HARv. L. REv. 895 (1968); authorities citcd note 8 supra.

30. On the need for judicial review of law cnforcement officers' discretion in order to assure that the rule of law prevails, see LAFAvE 68-72; H. Goldstein, Administrative Problems in Controlling the Exercise of Police Authority, 58 J. Crias. L.C. \& P.S. 1G0, 168-69 (1967) (excellent summary of various efforts to obtain review and the problems involved); LaFave \& Remington, Controlling the Police: The Judge's Role in Maling and Reviewing Law Enforcement Decisions, 63 Mfrcil. L. REv. 987 (1965); LaFave, Improving Police Performance Through the Exclusionary Rulc, 30 Mo. L. REv. 391 (1965).

31. Professor Goldstein concludes that the ultimate answer is not to legitimate police discretion and make attempts to control it through revicw, but rather to climinate police discretion and strive for full enforcement. The hope is that this would either force real reform of the statutory criminal law or follow such reform. See J. Goldstein, supra note 19 , at $560-62,586-89$. Whatever the validity of this view in regard to police, it setms impossible to endorse with respect to agencies, prosecutors and other law enforcement officers. In any case, the theoretical possibility of full enforcement is not dealt with here. The various judicial and scholarly justifications for enforcement discretion seem per. suasive, and the emphasis here is on obtaining review of such discretion in order to curb abuses. See Cox v. Louisiana, 379 U.S. 559, 569 (1965); CHALLkNGE, supra note 19. at 106: TAsK Force Report: The Police 18; H. Goldstein, Police Discretion: The ldeal fersus the Real, 23 Pub. Admin. REv. 140, 146; United States v. Cox, 342 F.2d 167 (ت̈h Cir. 1965); Powell v. Katzenbach, 359 F.2d 234 (D.C. Cir. 1965).

32. Since criminal estoppel rould result in a complete defense, the judicial determina. tion of police misrepresentation should have some impact on police practices. It inight force the police to re-examine the amount of discretion left to individual officers. For a discussion of why police departments are reluctant to formulate such policy now, sec Challenge, supra note 19, at 103-04; LaFave, 493-95; H. Goldstein, Police Discretion: The Ideal Versus the Real, 23 PuB. ADMIN. REv. 140, 143-45.

The judiciary is the best institution now available for considering the delicate issues involved. The courts are situated at the proper stage of the process for determining whether the accused has reasonably relied on official action or inaction because: (I) the police and prosecutor have had an opportunity to consider the propriety of their actions against the person, and (2) the principle is directly analogous to civil estoppel which the judiciary has dealt with over a long period of time. Being somewhat more inmune from the political pressure and tensions of law enforcement than the police and prosecutor. courts are better able to render considered decisions on the fairness of police and prosecutorial decisions and the reasonableness of the defendant's claimed relinnce on officials. misrepresentations. 
fendant's knowledge, ${ }^{33}$ it would properly be an affirmative defense. ${ }^{34}$ The defendant would bear the burden of coming forward with convincing evidence that the government had misled him, and the jury would decide whether he had actually acted in reliance on some offcial word or deed. ${ }^{35}$ The reasonableness of this reliance, ${ }^{30}$ however, determined in light of the policies weighing both for and against estoppel, would be an issue of law, since the courts will be defining the limits of the defense by specifying the circumstances in which reliance is justifiable. ${ }^{37}$

33. Those facts peculiarly within the defendant's knowledge would be those relating to his actual reliance-the knowledge of the pertinent law he had at the time of violation, what he heard the law enforcement officer to say, his belief in the advice or dircetions and his reliance thereon. However, in many cases highly important data might be just as "peculiarly" within the knowledge of the prosecution or police department, e.g., enforcement patterns, policy directives, the orders the law enforcement official was acting under. In such situations, ample discovery should be provided. See, e.g., People v. Harris, 182 Cal. App. 2d Supp. 837, 5 Cal. Rptr. 852 (1960).

34. Cf. 31 C.J.S., Estoppel $\$ 63$ at $397 ; \$ 75$ at $453 ; 153(1)$ at $743-49$ (1964). The criminal estoppel defense is heavily fact-oriented. Thus, the issue must be tried to the jury in some form. However, the prejudice to the defendant involved in trying the isstle to the jury could be nearly as great as that involved in trying the entrapment isstic to the jury. See Model Penal Code $\$ 2.10(2)$, Comment 5 at 14, 21-22 (Tent. Draft No. 9, 1959).

35. Since the defense is affirmative, the burden would seem to be best left with the defendant. However, the prosecution traditionally has the burden of proving all the elements of a crime "beyond a reasonable doubt." Moreover, the prosecution clearly has better access to the evidence on one half of the defense-official misleading; but the de. fendant has better access to the evidence on the other half-his own reliance. The treat. ment of burden of proof for the insanity defense is of some assistance herc. The defendant raising the insanity defense bears the burden of coming forward with evidence on the issue, the "production" burden. In half of the states and the federal courts, the defendant can satisfy this burden by presenting "some evidence" of insanity. By doing so, the defendant shifts the burden of production (as well as the persuasion burden) to the prosecution, which must present sufficient evidence of sanity to convince teasonable men beyond a reasonable doubt. The prosecution also bears the "risk of non-persuasion," though in a majority of states the defendant is said to have to prove his insanity by a preponderance of the evidence. See A. Goldstein, The Insantry Defense 110-15 (1967). Though the de. fendant can carry the issue to the jury by presenting "some evidence" (and Prof. Gold. stein indicates that this standard is liberally interpreted), he must demonstrate insanity by a preponderance of the evidence in order to get a directed verdict. The prosecution's burden to prove intent beyond a reasonable doubt is conceptually distinct.

There is some argument for applying this allocation in a criminal estoppel situation. However, the state's ease of access to evidence of misleading requires some variation. 'T"he proper solution would secm to be: (1) that the defendant should initially bear the pro. duction burden on both questions-misleading and reliance; (2) that if the defendant presents "some evidence" on both elements, the production burden and the burden of persuasion is placed on the prosecution on the question of misleading; (3) that the de. fendant retains the production burden and the burden of persuasion on the question of his own reasonable reliance; $(4)$ that the standard for a directed verdict should be that the defendant must prove his estoppel defense by a preponderance of the evidence unless the evidence presented raises a reasonable doubt as to intent or mens rea or another element of the crime. On mens rea, see note 77 infra.

36. Cf. 31 C.J.S. Estoppel $\$ 67$ (1961).

37. Since the criminal estoppel defense is based on due process, a matter of law, the trial court must exercise close supervision over the trentment of the entirc issuc. Where undisputed testimony demonstrates all the elements of the defense, or the defendant proves the elements of the defense by a clear preponderance of the evidence, the court should grant a directed verdict for the defendant. Where testimony on onc or more elements of 
Before a court can judge whether reliance on official misleading was justifiable, it will have to consider all the circumstances under which reliance is claimed..$^{38}$ Because the estoppel defense rests on due process notions of fairness to the individual, an abstract "reasonable man" standard that ignores individual characteristics will not do: ${ }^{30}$ the socioeconomic, educational, and cultural traits of the defendant, as well as those of the community in which he lives, ${ }^{40}$ are no less relevant to

the defense conflicts, mandatory instructions should be given the jury. Sec Movel. Pesia. CoDE $\$ 2.04(4)$ (Tent. Draft No. 4, 1955).

38. Cf. Bealle v. Nyden's, Inc., 245 F. Supp. 86, 92-j (D. Conn. 1965) for an cxample of a trial judge's treatment of all the facts and inferences available concerning the plain. tiff's reliance in a civil equitable estoppel claim.

39. This insistence on an individualized standard for reliance comports with the supreme Court's view of the due process mandate in another sensitive area of police practices-interrogations. Prior to the promulgation of the Mliranda rules, the Court's test for the admissibility of confessions obtained by police interrogation was "voluntariness," whether the defendant's will was overborn by the police conduct in questioning him. This seemingly objective standard became highly personalized in appliction. For example, in Crooker v. California, 357 U.S. 433 , 438 (1958) the Court states:

[The possibility of coercion] is negated here by petitioner's age [31], intelligence, and education. While in law school he had studied criminal law; indecd, when asked to take the lie detector test, he informed the operator that the results of such a test would not be admissible at trial absent a stipulation by the partics.

The Court then distinguished an earlier case that held that due process vas violated, House v. Mayo, 324 U.S. 42 (1945), because there the defendant was "an uneducated man" and a "stranger to the area." Another contrast to the Crooker determination is Spano v. New York, 360 U.S. 315, 321-23 (1959), where the Court noted that the defendant was foreign-born, only 25 years old, had no criminal record or exposure to police questioning. had finished only one-half year of high school, and had a history of emotional instability. before holding that the use of the confession solicited from him by the police through his "childhood friend" violated due process.

This individualized standard departs somewhat, however, from the normal treatment of reliance in civil estoppel and the mythical "reasonable man" of tort law: But it is apparent that the abstract "reasonable man" does tale on a very large number of the features of the defendant in a civil suit:

It would appear that there is no standardized man; that there is only in part an objective test; that there is no such thing as reasonable or unreasonable conduct except as viewed with reference to certain qualities of the actor-his physical attri. butes, his intellectual powers, probably, if superior, his knowledge and uie knowledge he would have acquired had he exercised standard moral and at least aserage mental qualities at the time of action or at some connected time.

Seavey, Negligence-Subjective or Objective?, 41 HARv. L. Rev. 1, 27 (1927). Sec gencrally W. PROSSER, THE LAW OF TORTS $153-83$ (3d ed. 1964). Whatever the benefits of the totally objective reasonable man might be in determining liability in civil matters (where the objective is to compensate victims and hold all citizens to a reasonable standard of care). the requirements of due process in the criminal estoppel situation should be made to turn on the reasonability of the defendant's reliance, since the objective here is to prevent the stigma of a criminal conviction from attaching to a person who has relied on the advice or directions of the executive officials. Cf. Moser v. United States, 341 IS. 41 (1951).

40. Significant practical difficulties, as well as definitional problems, are presented in determining a defendant's "community" and the community"s "mores." Certainly the relevant community should not be considered to be as large as a state juricelietion in most cases, nor as small as the defendant's private circle of friends or peer group. In a modern urban context the notion of a physically defimable community of mutually de. pendent actors with shared values and norms has only an attenuated meaning. The congruent social, economic, political and ethical worlds of the agrarian toun have disappeared; thus, there is substantial difficulty in determining the folkways or fundamental moral standards of conduct of citizens. Despite these problems, as long as the relevant com. 
determining whether the individual should have relied than to determining whether he actually did. At the same time, a standard of justifiable reliance cannot disregard society's interest in strict observation of the criminal law.11 Where the defendant knew that his acts were illegal, he must face a heavy presumption that reliance was not reasonable.42 The judge's task is to decide when, even after the official misleading involved in the case, the individual still has a duty to know the law.

Clearly, a mere expectation that the government will not prosecute does not raise the defense. ${ }^{43} \mathrm{~A}$ defendant who, for reasons not generally applicable, has received "license" 4 to violate the law from those charged with enforcing it cannot validly claim estoppel. The purpose of criminal estoppel is the protection of those whom the government has confused as to the state of the law; and collusion, bribes, and favoritism by officials are outside its scope-no matter how much the defendant may have relied on such misconduct. ${ }^{4 \bar{s}}$

Beyond this, however, a court can fashion few hard-and-fast rules for an estoppel defense. To rule on the reasonability of reliance, the court must juggle a complex set of factors. Besides the defenclant's personal characteristics, it must weigh in the balance the gravity of the

munity is dealt with as a function of the characteristics of the individual involved rather than according to such arbitrary classifications as political boundaries, the import of the factor of community standards can be preserved. Cf. Hall \& Seligman, supra note 1.

The relationship of the defendant's conduct to his community's standard of conduct may not always be helpful in determining whether reliance is reasonable. Where the person knowingly adheres to community mores, this should be some eviclence of the person knowingly of his reliance on official misleading. Where the defendant was not aware of the illegality of his acts, his deviation from community mores should not be considered to establish an "intent to deviate" that seriously jeopardizes the reasonability of reliance. The person's deviation from community mores may have little probative import on the question of reliance since the community in question may support a strict standard of conduct and the defendant may not endorse it or even be particularly aware of it.

41. See pp. 1051-52 supra.

42. Actual knowledge of illegality does not here require that the defendant have actual knowledge of a specific statute or statutes, but rather that he know his conduct is illegat in a functional sense, i.e., that under normal circumstances the proposed conduct would legitimately result in arrest and conviction if observed by law enforement officials. Whete the statute is vague or broadly phrased this type of knowledge would be more difficult to demonstrate. Where there is a selective nonenforcement policy or the statutc has fallen into desuetude, such functional knowledge of the statute would be required to raise the presumption. Cf. Ryu \& Silving, Error Juris: A Comparalive Stully, $24 \mathrm{U}$. Cuin. L. REv. 421,459 (1957).

43. See the discussion at note 16 supra of United States v. Associated Cen. Contractors of America, 238 F. Supp. 273, 283 (E.D. La. 1965), rev'd per curiam, 382 U.S. 17 (1965).

44. The sense of the term "license" here is "5. exceptional freedom allowed in a special situation. 6. excessive or undue fredom of liberty. . ." THE RANDOM HOUSE DictionAkY of THE ENGLish LaNGUaGe 826 (unabridged cd. 1967).

45. See, e.g., United States v. Cerone, 150 F.2d 382 (7th Cir. 19.15), wherc a criminal estoppel defense would be totally inapplicable since the defendants had colluded witl and bribed the officials involved in the case. 
offense, the ambiguity of the governing lawis and the degree to which its definition had been left to the administering agency, ${ }^{47}$ the means by which the government had misled the defendant, ${ }^{48}$ and the extent to which a citizen should be charged with knowledge of the internal workings of government. ${ }^{9}$ Some, if not all, of these considerations will also bear on the jury's determination whether the defendant was actually misled, but the court must look at them in a different light. The question for it is not what the defendant did, but how great a margin of error the public interest can permit and due process may require in cases like his. ${ }^{50}$

46. The Court stated in Cox v. Louisiana, 379 U.S. 559 (1965), that though the statute involved passed constitutional muster on vagueness grounds, some ambiguity remained: "near" a courthouse could have different meanings to different people. Sce note it supra. The Court felt that the statute foresaw an administrative interpretation to clarify it in a particular situation. Remington and Rosenblum have stated that the arerage state's criminal law is permeated with ambiguities and inconsistencies necessitating a great deal of administrative discretion. Some such ambiguities result from legislative inerita or the ineffective use of language, but others clearly result from legislative design-lo facilitate administrative problems, to eliminate possible loopholes, or to deliberately delegate policy decisions to law enforcement agencies. Remington \& Rosenblum. The Criminal Lau' and the Legislative Process, 1960 U. ILL. L.F. 481, 483-93 (1960). All of this lends much support to the arguments for allowing law enforcement agencies to excrcise discretion. but it also means that the area of functional illegality in much of the substantive criminal law has hazy contours indeed. Similarly ambiguous standards are created b) some common law defenses such as self-defense or the right to defend onc's property with reasonable force. The result of criminal laws that are ambiguous but not void-for-vagueness, see note 10 supra, is to create a large zone of actions which are possibly criminal where the private actors will place great reliance on an official's interpretation of legality.

47 . For example, courts are much more inclined to allow wide discretion to federal administrative agencies (in defining the scope of a regulatory statute, in selecting remedies, and in rule-making) than they are to recognize police discretion in regard to normal criminal statutes. This may be due to a number of factors: greater faith in the "special competence" of the agency than of the average police department, the realization that agencies generally initiate the criminal sanction as an incident to economic regulation, and an awareness that regulatory statutes generally grant rule-making powers to agencies that are not granted to police. See Moog Industries v. FTC, 355 U.S. 411 (1958); Bryce Motor Lines, Inc. v. United States, 342 U.S. 337 (1952); Jacob Sicgel Co. v. FTC, 327 U.S. 603 (19H6). Where a defendant relies on misrepresentations of an agency that has a great deal of recog. nized authority to define the manner and occasions of a law's enforcement. the reason. ableness of his reliance would seem clear in most cases.

48. Three main categories of official misleading will be dealt with in this Note-bv order, by opinion and by selective non-enforcement. However, cadi of these categorier admits of any number of nuances such as whether the inisrepresentation was written or oral, whether the official who misrepresented the law had actual authority to give a correct decision. Cf. Comment, Estoppel Against the Govermment in Califorin, 14 CiLf. L. Rn. $340,342-44,352-53$ (1956).

49 . In some civil cases where courts have refused to apply estoppel against the government, plaintiffs have been held to a very high degree of knowledge of the govermment. See, e.g., Federal Corp Ins. Corp. v. Merril, 332 U.S. 380, 383 (19.47); note 23 supra. Hover, the main thesis of this Note is that due process will not allow a similar standard when a criminal conviction is at stake.

50. Although the courts may be reluctant to allow the estoppel defense in a situation that could recur with some frequency, each case should be dealt with individually; if the requirements of estoppel are met, frequency of occurrence may be material. Other prospective factors, perhaps even the instant decision that an official had misled the defendant and thus created an estoppel (if the next defendant was aware of the decision or should have been), may intervene to make the reliance of later defendants on the same type of misleading unreasonable. 


\section{Nature of the Offense}

Common sense suggests that the more serious an offense is regarded, the more urgent is society's interest in its strict prevention and deterrence; for similar reasons, a jury will be less likely to find actual reliance when the crime is a serious one. The distinction between mala in se and mala prohibita at first seems to provide an easy line of demarcation, ${ }^{51}$ but the clarity of this distinction has eroded over the years until now it connotes little except an historical contrast between the old common law crimes and the newer statutory ones. ${ }^{62}$ For purposes of the analysis here, it seems helpful to differentiate between crimes involving great physical cruelty and injury; ${ }^{53}$ crimes involving substantial personal injury; ${ }^{54}$ crimes involving substantial theft or destruction of property or a serious disruption of the public or economic order; ${ }^{55}$ vice crimes; ${ }^{56}$ and finally violation of regulatory statutes, "public welfare laws," and minor misdemeanors."57

Estoppel can never be a valid defense to a charge of an heinous

5I. See, e.g., People v. Ferguson, 134 Cal. App. 41, 24 P.2d 965 (1933), where the court mentions the distinction and, since the securities offense involved was malum prohibilum, allows an estoppel defense.

52. The distinction often seems to embody a gross moral judgment based not on contemporary standards, but the common law or vague notions of natural law. See Sayre, Public Welfare Offenses, 33 Colum. L. REv. 55, 70-71 (1933). However, it may retain content for some commentators as a label for those crimes that require mens rea is an element of the offense as against those that do not. See Hall \& Seligman, Supra note 1, at 642.

53. Such "heinous" crimes involve such markedly cruel physical treatment of other persons as to involve shocking disregard for the dignity of life and person. Murder in the first degree and second degree, forcible rape, compulsory prostitution, forced addiction, and sabotage or bombings in reckless disregard of life would fall into this category. $C f$. Advisory Council of Judges of the National Council on Crime and Delinquency, Model Sentencing $A c t, 9$ Crime \& Delin. 339, 355.6 (1963). This category is in no sense analytically discretc, and implies a moral judgment about the offensiveness of particular crimes. Rational discussion of types of crimes requires some such judgment where the question involved is the reasonability or justifiability of reliance on official misleading.

54. This class of crimes would include all crimes that would be in the category of heinous crimes, see note 53 supra, but for the absence of the surrounding circumstances that makc those crimes shocking. It also includes manslaughter, negligent homocide, assaults and such other offenses where real injury to another person takes place.

55. Property taking or damaging crimes should include all crimes such as theft, shoplifting, burglary, robbery, destroying public or private property, unatuthorized major strikes, price-fixing, etc. where the negligent or reckless disregard of life of the catcgories heinous crimes or injury to persons is not involved. See notes 53-54 supra.

56. "Vice" crimes are those which involve conduct the legislature decms morally deviant although no direct injury is involved to any other person or property such as narcotics, liquor, sex and gambling laws.

57. These three types of crimes are discussed together because they generally involve no deviation, or at least no generally acknowledged deviation, from community mores in violations and because there is usually no direct injury to any person or property involved in violations. (Financial or other loss can be adequately compensated by civil liability.) Regulatory statutes should be taken to include health codes, tax laws, sccurities and corporations laws, labor statutes, motor vehicle laws and others. Minor crimes include breach of the peace, disorderly conduct and other misdemeanors. For an analysis of the term "public welfare laws" see Sayre, Public Welfare Offenses, 33 Colum. L. Rev. 55 (1933). 
crime. The consequences of such an offense are so severe and the act itself so reprehensible that society cannot permit a doubt as to the law -no matter how well-founded-to serve as an excuse for a violation. Individuals will never have good cause to approach the "zone of unlawfulness" here and the government has every reason to keep them away from it. ${ }^{58}$ Moreover, the law is rarely ambiguous with regard to these crimes, and they deviate so far from community morals that their wrongfulness should be apparent even in the face of official misleading. 59 For similar reasons almost any crime involving substantial personal injury would be outside an estoppel defense. Society has the strongest interest in preventing these offenses and actual relinnce on official misleading is unlikely in the face of the injured party's universally recognized moral right to bodily safety. Where the victim has in some way provoked the crime, however, widely held views on the right to protect one's own person, property and dignity may create uncertainty as to the law-especially when the law itself has granted some legitimacy to such views. ${ }^{60}$ Since legal and moral notions about matters like self-defense have already introduced ambiguity into the criminal law here, recognizing a claim of estoppel would not seriously weaken the deterrent force.

The need for deterrence is nearly as great when the offense threatens serious damage to property or to the public or economic order, but at this point the law becomes much more ambiguous. Confusion as to the existence and extent of intangible rights in property can present many situations where the defendant might reasonably seek and rely on official advice. ${ }^{61}$ Serious disturbances of the public order often arise from the exercise of rights of speech and protest, where the individual has the sanction of the Constitution in approaching near the zone of

58. This "shocks the conscience" standard is obviously vague, but no court or jury will have difficulty ascertaining that the defendant's reliance was totally unreasonable and unjustifiable in a given case. The preventive interest of socicty is so paramount as to render absurd the raising of an estoppel defense.

59. The statement that heinous crimes deviate from community mores would be circular were it not for the problem of civil disorder. During civil disorder law and perhaps mores have completely broken down in a significant body of the population in a community. The difficulty this creates for a defense based on a legal docurine such as estoppel and the question of reasonable or justifiable reliance is obvious.

It should also be noted that reliance by insane persons is bejond the scope of this Note, except to point out that the insanity defense and the criminal estoppel defense are basically inconsistent since legal insanity is defined in terms of lack of control and lack of knowledge of right and wrong.

60. See generally Model Penal CODE $\$ \S 3.04-3.06$ and Comments (Tent. Draft No. 8. 1958).

61. See, e.g., Moder Penal Code, $\S 206.10$ (Tent. Draft No. 4, 1955) and Comments (Tent. Draft No. 2, 1954) at 98. 
unlawfulness. ${ }^{62}$ Even grave economic offenses may be similar to conduct which is lawful as well as profitable. ${ }^{63}$ Entertaining an estoppel defense to charges like these would not only import more fairness into the criminal process, but would reduce undesirable chilling effects of the substantive law.

The category of vice crimes includes a wide variety of offenses, but they have in common the purpose of preserving the moral fiber of those tempted to commit the crime. Because the injury to society is problematic at best, an individual seeking to comply with these laws might justifiably rely on official advice and enforcement practices. ${ }^{\text {(4t }}$ Moreover, mores in many communities are changing rapidly on matters involving sex, drugs, liquor, gambling, and the other objects of vice statutes, thereby out-dating the law and giving further support to a claim of estoppel. ${ }^{65}$

If a criminal estoppel defense were generally available, however, its importance would be greatest in prosecutions under regulatory statutes, public welfare laws, and the minor crimes of numerous types and varying scope which pervade American life. ${ }^{66}$ Frequently, these statutes do

62. See, e.g., Cox v. Louisiana, 379 U.S. 559 (1965).

63. See, e.g., United States v. Socony-Vacuum Oil Co., 310 U.S. 150 (1940). But se't, notc 16 supra.

64. Such reliance would be even more likely where official advice is coupled with a selective nonenforcement policy. See pp. 1069-72 infra. However, if the acts involved are clearly illegal (e.g., prostitution) and known to be so by the relying party, it is lard to see how one could reasonably expect that the permission would last beyond the scope of that official's power. Where the acts violate community mores, this inference is cven more persuasive. But where the legal question is unclear and community mores also permit or endorse the acts (e.g., social gambling), reliance absent notice of a policy change should
offer a valid estoppel defense.

On social gambling and the special problems of current practices in this area, sec LAFAve 89-91, 148-9, 155-6; H. Goldstein, Police Discretion: The Ideal I'ersus the Real, 23 Pub. Adin. Rev. 140, 141-2 (1962).

The estoppel defense should not be used as a means to wed police, prosecutor, or ad. ministrative agency to their present policy, but the type of prospective notice to which these officials should be held in order to change policy is a significant problem. $A$ strict standard (i.e., that the notice was insufficient if it did not reach the defendant trying to raise the estoppel defense based on the old policy), might well be considered too lieavy a burden to place on the government. The standard of notice should, however, reflect the basis of the estoppel defense, reasonable reliance, and thus demand of the official a reasonable effort to use the reasonable means available to notify all persons who call be expected to be affected by the change of policy.

65. Professor LaFave prefers to conceptualize the situation of nonenforcement of gambling laws against social gamblers as a case where the legislature male certain conduct subject to the criminal law to insure against creating a loophole through which scrious offenders could regularly escape. See LAFAvE 89-91. Thus it could be said that social gambling is not within the legislative intent. This may provide a justification for a selective nonenforcement pattern, but it provides no protection for unknowing persons arrested when police "abuse" their discretion and violate the legislative will by following the
clear language of the statute to arrest social gamblers.

66. Such offenses are generally considered less serious in nature and thus less likely to deviate substantially from community mores. By the same token the defendant's claim of lack of knowledge of the illegality of his acts and his claim of reasonable reliance on 
not so much prohibit harmful conduct as require that perfectly lawful undertakings be conducted in a particular way, in order to facilitate government supervision of the activity. These rules-of-the-road laws usually have little to do with common notions of good and evil, and the defendant unaware of their existence will get no warning from his moral instincts that his conduct may be criminal. ${ }^{07}$ Most important, such statutes often commit broad rule-making powers and discretion to the enforcing agency, leaving even the knorwledgeable individual ${ }^{o s}$ no other reliable guide to the law. The ambiguity or complexity of many of these laws only compounds this dilemma. ${ }^{09}$ Under these circumstances, an estoppel defense, once raised, should be persuasive.

\section{Nature of the Misrepresentation}

The second major factor in determining whether reliance on official misrepresentation was justifiable is the form that such misrepresentation took. Government long ago grew too large and complex to be bound in every case by the words or actions of each of its agents. Often, misrepresentation may result from a miscomprehension of what the official said or did. Since actual reliance is difficult to disprove after the defendant has shown some misrepresentation-the criminal act itself providing some evidence held that he relied 0 - the defense would become overly subject to abuse were any act of any agent capable of estopping the government. The court may determine, in light of the conflicting demands of justice and order, how much knowledge and comprehension of the government agent's actual authority the defendant should be held to possess. ${ }^{71}$

Estoppel by Order.-The clearest case for justifiable reliance is that in which a recognized official orders the defendant to perform acts in violation of the criminal law..$^{2}$ A private individual should not lightly

official misleading will both be more credible. Similarly, police and prosecutorial discretion are more accepted and expected in these areas. See Cox v. Louisiana, 379 U.S. 559, 569 (1965); J. Goldstein supra note 19, at 60-62; H. Goldstein, Police Discretion: The Idcal Versus the Real, 23 PuB. ADMIN. REv. 140, 142-43 (1962). Comment, The Right to Nondiscriminatory Enforcement of State Penal Lau's, 61 CoLUM. L. REv. 1103, 1119.22 (1961).

67. See, e.g., State v. Ragland, 4 Conn. Cir. 424, 233 A.2d 698 (1967); Pcople v. Markowitz, is N.Y.2d 953 (1966), 227 N.Y.S.2d 149, 223 N.E.2d 572 (1960).

68 . A defendant experienced in the workings of the law enforcement agency should naturally be held to a higher standard of understanding of the actual authority of the agents with which he deals. See also notes $89-90$ infra.

69. See note 46 and accompanying text supra. See also People v. Ferguson, 134 Cal. App. 41,24 P.2d 965 (1933).

70. See notes 33-35 supra.

71. See notes 39,68 supra and note 90 and accompanying text infra.

72. There is a certain amount of ambiguity in the term "order" since statements meant and understood as requests are often phrased in the imperative. An "order" should be 
disregard the reasonable orders of authorized public officials, ${ }^{73}$ and this fact alone will usually justify reliance whether or not the defendant knerv the ordered acts were otherwise illegal. Yet an official order cannot absolve the citizen of responsibility for all acts in compliance with it: ordered to commit plain murder or robbery ${ }^{74}$ the citizen must refuse. Crimes involving substantial physical injury to any person would seem to deserve similar summary treatment where an estoppel by order defense is presented. ${ }^{75}$ Yet such acts may not resemble criminal conduct at all under some circumstances: for example, when a policeman orders a bystander to help him subdue someone resisting arrest, the inherent ambiguity of the situation may reach the point that justifiable reliance on an official order to cause substantial injury is possible.

Reliance is more clearly justifiable when the acts ordered by the official do not involve inflicting injury on another. In Schiff v. People

taken to mean a command that implies a real threat of some sort of punishment, either legal arrest or positive extra-legal detriment, to the person commanded if the command is not obeyed. See, e.g., note 80 infra. On this basis, an order can be distinguishcel from an opinion or request with normative import in that the latter implics only displeasure on the part of the misleading official with conduct that deviates from the request, or the possibility of future legal or extra-legal detriment to the relying party.

73. See, e.g., State v. Ragland, 4 Conn. Cir. 424, 233 A.2d 698 (App. Div. 1967). A policc officer ordered the defendant to drive his vehicle to police headquarters to post a bond after the defendant had requested a ride in the police cruiser. Though the defendant dicl not inform the police of the fact, his "right to operate" a motor vehicle in Connecticut was under suspension. He was later charged and convicted of driving while under suspension. The Appellate Division reversed his conviction for driving to the police headquarters, stating:

[W] hen one is affirmatively ordered by a police officer . . . to perform a certain act and in the performance of that act one violates a statutc, a conviction should not obtain.

Id. at 426,223 A.2d at 701 .

The fact that the defendant first asked to ride to headquarters in the police cruiser could indicate that he knew that his license was under suspension and that his driving in Connecticut was illegal. If this were the case his reliance would appear to be on the ignorance of the officers rather than on the order to drive to headquarters. Thic court avoided this problem by stating that the defendant had no obligation to reveal his motor vehicle record to the police. Id. at 427, $233 \mathrm{~A} .2 \mathrm{~d}$ at 702 . This may well be justification for nondisclosure when the relying party is already under arrest as in Ragland or where the disclosure would reveal present or past criminal conduct and thus bring self.incrimination rights into play. However, in the normal situation reliance, and the criminal cstoppel defense, could never be based on a partial disclosure of the relevant facts involved in a proposed course of conduct. Actually, in Ragland the court was probably relying on the public interest in rapid obedience to the orders of officers charged with traffic regulation, a policy embodied in 14 CONN. GEN. STATS. 223.

74. Cox v. Louisiana, 379 U.S. 559, 569 (1965).

75. The relying party should, however, be liable for damages done to a third person if a reasonable person would have recognized the risk of injury with normal attention and care. See RESTATEMENT (SECOND) OF TORTS $\S 289$ (1962). The state should also be liable for damages done to third persons by the relying party based on official misleading. Sce RESTATEMENT (SECOND) OF TORTS \& 311. But see 28 U.S.C. 1346(b) (acknowlectging liabillty for acts done by employees of the government within the scope of their offices); cf. 28 U.S.C. 2680 (b) (no liability for exercise of discretionary function, even if cliscretion is abused).

76. ill Colo. 333, 141 P.2d 892 (1943). 
the conviction of a junkdealer for larceny in retaining stolen property he had purchased unknowingly was reversed; the appellate court stated that since the police directed the defendant to hold the property he lacked criminal intent:

The hold order was a condition imposed by the police for the benefit of ... the complaining witness, and Schiff should not be penalized for following the instructions of the police, even though it later develops that the police instructions had no legal basis in fact. His retention of the property in reliance upon the police order does not constitute an "intent to steal," which is one of the essential elements of the crime under the statute.it

Orders by officials with a good deal of discretion in enforcement of regulatory statutes or by police in regard to minor crimes or vice crimes $^{78}$ offer an all but irresistible case for estoppel. Sufficient discretion makes an official by and large the law-maker, the ordinary citizen cannot be expected to challenge the legal accuracy of the order and

77. Id. at 336. The court's use of the concept of mens rea to reserse a conviction resting on facts that would bring the case squarely within the estoppel defense presented in this Note raises the question of the degree of overiap between llese two conceptual approaches to acquittal. One view of mens rea equates it with culpability of any kind necessary for a fair imposition of criminal responsibility and hence sees cases of nonculpable ignorance of the law as involving basic mens rea principles. See Packer. The Supreme Court and Mens Rea, 1962 Sup. Cr. REv. 107; Hart, The Aims of the Criminal Law, 23 LAw \& ConTEIP. Prob. 401, 404-06 (1958). Orthodox mens rea requirements overlap with the estoppel defense to the extent that official misleading has led a defendant to a mistaken view of the circumstances of his conduce so that under his view of the circumstances his conduct is not a crime. This was essentially the situation the court found in Schiff. See also Morissette v. United States, 342 U.S. 246 (1952). Howeser, the Model Penal Code treats its limited estoppel defense separately from its general provision that mistake of law is a defense if the mistake "negatives the purpose, knowledge, belief. recklessness or negligence required to establish a material element of the offense. ...: MOdel PeNal CoDE $\$ 2.04(\mathrm{l})(\mathrm{a})$ and $\$ 2.04(3)(\mathrm{b})$ Comments at 138-39 (Tent. Draft No. 4. 1955). The rationale for the distinction that is offered in the comments is that the defense would normally apply to mala prohibila where the penal sanctions are appropriate only for deliberate evasion and a single violation does no major public injury. Id. at 138 . In these types of crimes the mens rea requircment is attenuated beause the crime is one of strict liability or presumed intent, and thus the estoppel defense is clearly the preferable rationale. However, there are other cases where presumably mens rea could be shown, but there are sound reasons not to allow a conviction. Cox v. Louisiana, 359 U.S. 559 (1965); Bouie v. City of Columbia, 378 U.S. 347 (1964); State v. Jones, 44 N.MI. 623, 107 P.2d $324(1940)$.

The "wilfulness" standard has sometimes been read by courts to excuse good faith errors by defendants about the law whether or not the product of conduct would give rise to the estoppel defense advocated here. United States v. Murdod, 990 US. 359 (1933): United States v. Mancuso, 139 F.2d 90 (3d Cir. 1943). This tack is sometimes woefully deficient as, for example, in James v. United States, 366 U.S. 213, 291 (1961), where the Court stated that its reversal of an earlier decision (under which the defendant would not have been guilty of income tax evasion) made it analytically impossible to convict the defendant under a wilfulness standard. Surely an estoppel framerork for this decision, although it does not involve executive misleading and thus is beyond the scope of this Note, would have been preferable.

In any event, the doctrine of mens rea provides strong support for the costoppel defene. presented here. See generally Hall \& Seligman, supra note 1.

78. See LAFAve 71 nn.32-33. See also note 64 sipra. 
the official's legal power to give it. ${ }^{70}$ As one judge pointed out in a case where the police had ordered an obviously drunk defendant to drive off, and then arrested her for it:

The average citizen does not argue with uniformed authority; when the law suggests "Move on," the healthy instinct is to get going. Moreover, one in the defendant's condition cannot be expected to discuss with reasoned calm the merits and dangers of proposed action. ${ }^{80}$

Estoppel by Opinion.-When a government agent did not order the defendant to act, but merely advised or suggested that the conduct did not violate the law, the issue of justifiable reliance is more difficult to resolve. The official may have urged a course of action on the defendant, giving his opinion as to the lawfulness of the action some of the persuasive force of an order, ${ }^{81}$ or he may only have signified tacit consent. The defendant may have sought out the opinion, or the official may have announced it unsolicited. The agent whose opinion is put forward as grounds for estoppel may have been the logical official from whom to seek advice, ${ }^{82}$ or he may have had no apparent authority to

79. See note 73 supra.

80. Pcople v. Donovan, 279 N.Y.S.2d 404, 406 (Ct. Spec. Sess. 1967); Case Note, 81 Harv. L. Rev. 895 (1968). Police summoned by a homcowner found an intoxicated motorist parked in a driveway, and informed the defendant that she was on private property and would have to leave. They then left and waited down the road until the defendant drove out on to the public highway and arrested her for drunken driving. Interestingly, Section 1102 of the Vehicle and Traffic Law of New York makes it an offense to fail to obey any order of a police officer, but the judge found that the police officer's statements did not amount to an order. Id. at 406. At this point it "occurred" to Judge Friedman that estoppel could apply against the state in such a case. Id. at 406 .

81. On the facts, Cox probably should be considered as an example of stuch a normative opinion. The Chief of Police, who may not even have been aware of the courthouse picketing statute, was apparently saying that the demonstration should be conducted across thi street from the courthouse. This, however, could not be considered an order since Cox had already refused to obey the Chief's order to turn back. Cox v. Louisiana, 379 U.S. 559,571 (1965).

82. Many federal, state and local statutes require the issuance of permits or licenses by duly constituted public agencies or officials before certain activities can take place. W'licre a person has been granted a permit or license, this fact should create a valid estoppel defense for acts that officials would naturally expect to be performed under the permit or license which are not otherwise illegal. For example, the issuance of a driver's license to a person who has answered all reasonable inquiries of the licensing anthority and sought the license in good faith should create a valid estoppel defense for prosecution for unlicensed driving where it is later discovered that the party is incligible for licensing. Where the party is told by the proper authorities that a license is not required for the proposed activity, this should create a valid estoppel defense for conducting those activities without the license. People v. Ferguson, 134 Cal. App. 41, 24 P.2d 965 (1933); Pcople v. Markowitz, 18 N.Y.2d 953, 277 N.Y.S.2d 149, 223 N.E.2d 572 (1966).

The apparent authority of the agent is far more important than the actual authority in determining reasonable reliance in criminal estoppel cases. However, depending on the knowledge and status of the relying party, it might reasonably be said in some cases that he knew or should have known the limits of the authority of the agent he was dealing with. This is not to say that the government in the criminal arca should be bound by the same standards of apparent authority that a private corporation or partnership is held to. 
offer advice under the law in question. All these variables are important to fixing the point at which the government's duty to stand by its agent's clarification of the criminal law ends and the citizen's duty to know it begins.

There is, for example, no basis for estoppel if an official's consent to certain conduct suggests only an offer of individualized immunity from arrest or prosecution. ${ }^{83}$ Policemen sometimes give license to violate the law, especially in the area of vice and minor crimes. ${ }^{* t}$ Usually these cases also involve conduct that is plainly illegal, so that the defendant has no reason to believe that the permission carries any legal force. Where the official's license is but a particular instance of a general policy of nonenforcement, ${ }^{85}$ however, a valid estoppel claim is presented.

A similar problem arises where a statute necessarily commits a great deal of discretion to the enforcement agency, and different officials can reasonably and properly assess the same situation differently. For example, police may visit a party upon complaint and advise those present not to become louder. Although the noise level remains the same, other officers later arrive and arrest the host for disturbing the peace. Unless he was assured by the first officers that his conduct was unquestionably within the law, the defendant in such a case should realize he was relying on little more than their individual discretion. ${ }^{86}$ Moreover, opinions about such laws as breach of the peace statutes

See generally Whelan \& Dunigan, Gouermment Contracts: Apparent Authority and Estoppel, 55 GEO. L.J. 830 (1967).

83. The purpose of an estoppel defense is to prevent the criminal sanctioning of conduct performed in reliance on official advice that it was legal or at least not currenty punished as a uniform policy. Official favoritism or unreasomable leniency are not legitimated by the defense because the essential good faith element is missing-the defendant vould bnow that the permission is not a legal grant to all persons similarly situated but rather an extra-legal license that amounts to an abuse of the official's discretion. See notes 44,45 supra.

84. For example, a policeman might advise combatants to "fight it out" around the corner, not in public view. He is offering the combatants his own personal immunity from an assault or breach of the peace charge, not a legal opinion, and his words are probably understood as just that.

85. See pp. $1069-72$ infra. criminal process within the "full enforcement" area. See J. Goldstein, supra note 19. at $557-60$. Howerer, police discretion is such a widely accepted aspect of the criminal process that reasonable reliance on reasonable discretion should be considered to be a valid form of estoppel.

The situations in which police mislead by opinion will usually be informal queries addressed to patrolmen or officers. Where this is the case, the question of whether the official response was a granting of a "license" rather than a statement as to legality will be crucial. Where the inquiry is more formal, it is more likely to be addressed to the prosecutor or district attorney than the police. However, unusual situations such as that in Cox occur with some regularity in organized protests and incidents of controlled civil disobedience. 
carry the implied qualification that reliance is reasonable only so long as the situation remains unchanged-and it can change whether the defendant alters his conduct or not. ${ }^{87}$

Most cases of estoppel by opinion will involve regulatory and public welfare statutes ${ }^{88}$ where the opinions and practices of the administering agency actually define the scope of much of the law. Recognizing the need for their advice, many such agencies have institutionalized the giving of opinions ${ }^{89}$ and where the defendant has received and followed advice of this type, he has a compelling claim to an estoppel defense. On the other hand, a party acting through counsel or experienced with the agency procedure ${ }^{00}$ would have substantial difficulty demon-

87. Thus, to return to the party example, a given noise level may be tolcrable at 9:00 p.m. and yet be considered illegal at 2:00 a.m. However, the feature of the situation that changes sufficiently to make further reliance unreasonable must be a feature that is reasonably related to the supposed illegality.

88. The fact that laws in this category often involve relatively minor offenses does not mean that official orders to perform an illegal act may not have serious consequences. The drunken driver ordered to drive home may kill someone on the way. The slumlord is ordered to keep his tencment open in spite of the rats, and a tenant's child may be injurcd by rat bites. However, the reasonability or justifiability of reliance should be judged by the circumstances at the time of the reliance; later fortuitous events may be grounds for tort liability against the individual or the state, but not a determining factor in criminal liability. See note 73 supra.

89. For example, the Department of the Treasury issues guidance to taxpaycrs under the authority of INT. REv. CODE OF 1954, § 7805. The "advice" comes in the form of Treasury Regulations, Revenue Rulings, Revenue Procedures and private determination letters. See B. Bitrker, Federal Income, Estate and Gift TAxation 25-28 (1961).

Similarly, the Department of Justice's Antitrust Division gives advice on business conduct in relation to the antitrust laws through its "Business Review Procedure." Antitrust Division Directive No. 2-68 sets up stringent requirements for the issuance of a business review letter by the Division: a request for revicw must be submitted in writing and can only involve proposed business conduct; the requesting parties "are under an aflirma. tive obligation to make full and true disclosure"; no oral releases can bind the enforcement policy of the Division, a business review letter states only the enforcement intentions of the Division as of the date of the letter and the Division remains completely frec to alter its intention in the public interest (although, the Directive states, the Division "lias never exercised its right to bring a criminal action where there has been full and true disclosure at the time of presenting the request'); a final caveat states that a failure by the Division to take action after the receipt of a request and accompanying documents does not in any way estop the government from taking any appropriate action thercafter. 28 C.F.R. 50.6.

Thus, it is apparent that the Division considers itself not to be binding itself in any way by issuing a business review letter in regard to business conduct. It has been held that such clearance does not bind the Division. United States v. Joscph Schlitz Brewing Co. 253 F. Supp. I29 (N.D. Cal. 1966). However, Schlitz was a civil action and thus not related to the criminal defense offered here. On the criminal side, United States $v$ Socony-Vacuum Oil Co., 310 U.S. 150, 226 (1940), was the last antituust case that involved an estoppel fact situation. See note 16 supra.

90. Perhaps the greatest instinctive difficulty with a criminal estoppel principle is its application in fields of law where lawyers abound and one can justifiably fear that the government might be taken advantage of. Obviously, the reasonableness standard for reliance would be very high where the private party employs legal talent to deal with the government. Moreover, experienced counsel should be held to have known the actual authority of the agent with which he is dealing. There is also the question of whether the party is actually relying on the misleading of the government or the independent judgment of his own attorney. It is not necessary that the official misleading be determined to be a "but for" cause of the offense, but to the extent that the party is relying on counsel the 
strating reasonable reliance on an opinion which did not emerge from the institutionalized process. ${ }^{91}$ Reasonable reliance will usually require that the defendant obtained his advice by pursuing whatever regular channels are clearly available.

Whether an opinion of one agency can cross jurisdictional lines to estop another must ultimately depend on how plainly the lines are marked. Where the second jurisdiction is a separate government altogether-as in the case of different states, or the federal government and a state-the opinion can never have the power to estop. ${ }^{02}$ Even when the party did not know that his acts might violate the laws of another jurisdiction, the public interest in ensuring that legislativelydesignated administrators of a given statute retain control of its enforcement would foreclose the defense. One government cannot be charged with the responsibility of educating the officers of another, however likely it is that these officers might render opinions. Normally the same no-estoppel rule should apply to separate agencies within the same government. ${ }^{93}$

Estoppel by Selective Nonenforcement.-Of course, principles underlying the concept of estoppel apply no less to what government officials do than to what they say. Patterns of enforcement and nonenforcement could well ground a criminal estoppel defense. ${ }^{94}$ Selective nonenforcement is common to all enforcement agencies, ${ }^{95}$ the practice

estoppel defense is diminished. Reliance on private counsel is not and should not be a defense to a criminal action. Hall \& Scligman, supra note 1, at 652-53: Rju and Silving. supra note 30 , at 439 .

91. This is the basic fact situation in United States v. Socony-Vacuum Oil Co., 310 U.S. 150 (1940). See note 16 supra.

92. See United States v. Philadelphia Nat'l Bank, 374 U.S. $321,350.52$ (1963); California v. Federal Power Commission, 369 U.S. 482, 484-5 (1962).

93. A possible exception to this rule might be found in cases where separate agencies have jurisdiction over the same laws, e.g., the FTC and the Antitrust Division.

94. As stated in Cox and Raley, the due process requirement for a criminal estoppel defense is unequivocal in the case of an individual misled in an ad hoc situation when the state, through the executive, is focusing attention on his conduct. Howerer, due the state, through the notection does not faror individuals who were denied their rights in a direct confrontation with the state as against those who were denied their rights by indirection. See, e.g., Griswold v. Connecticut, 381 U.S. 479 (1965); Johnson v. United States, 318 U.S. 184,197 (1943); Pierce v. Society of Sisters, 268 U.S. 510 (1925). The issue is whether the individual was reasonably misled by inconsistent positions taken by the government, not "Year Book distinctions between feasance and nonfeasance." Lambert v. Califormia. 355 U.S. 225, 231 (1957) (Frankfurter, J., dissenting). Certainly, civil estoppel principles do not recognize such a distinction. 31 C.J.S. Estoppel $\$ \$ 72,87$.

95. See J. Goldstein, supra note 19, at 560-62; H. Goldstein, Police Discretion: The Ideal Versus the Real, 23 PUB. ADMIN. REv. 140, 142-43 (1963); LAFAVE 61-72, $492-95$.

A strict nonenforcement policy is that which exists when the police or prosecutors do not enforce a given criminal law or laws under any circumstances. Over a sulficiently long period of time such a law is said to have fallen into desuetude. See Bonfield, The Abrogation of Penal Statutes by Nonenforcement, 49 Iow L. REv. 389 (1901); Poe v. Ullman, 367 U.S. 497 (1961). But see Jones v. Alfred H. Alajer Co., 392 US. 409 (I96S): District of Columbia v. John R. Thompson Co., 346 U.S. 100 (1953). However, a selective 
going far beyond the inability to investigate and prosecute all violations because of inadequate resources. ${ }^{90}$ Police, for example, often choose not to enforce a statute against classes of violations which they and the community do not regard as serious. Gambling statutes and some pub. lic welfare statutes such as housing code violations provide perhaps the most familiar example of laws enforced selectively for this reason. ${ }^{17}$ In other cases, the enforcement agency may regard offenses that fall below a particular quantum of violation too trival to pursue: tame drunks and brawlers typically lie below the level of criminal conduct that police consider worth their notice. ${ }^{88}$ Whenever the law goes largely unenforced against a particular class of violations for reasons which suggest that officials do not really want to sanction these violations,"

nonenforcement policy is that under which police do not enforce a given criminal law or laws against certain types of persons, during certain times of the day, in certain geo. graphical areas, or in certain types of factual situations though police are aware of violations and could enforce the law. See generally LAFAve 61-164; J. Goldstein, supra note 19 , at 558-59.

Thus, classes of persons which have not been the subject of law enforcenent for a particular statute though there have been noticeable (to the police or prosecutor) violations may rely on the continuation of that nonenforcment. The problem of determining identifiable classes is substantial in any given fact situation. However, the misleading of the citizen by the state and his reasonable reliance are the governing factors in determin. ing the class. The offense to fundamental fairness involved in official misleading is not dissipated by the fact that large numbers of persons are misled; rather, such practices strikc at the heart of fair government. "Engrained in our concept of due process is the require. ment of notice." Lambert v. California, 355 U.S. 225, 228 (1957). This requirement cannot reasonably be met when the executive has contradicted the legislative purpose cmbollied in a criminal statute by refusing to enforce it. See LAFAvE: 69 .

96. See J. Goldstein, supra note 19, at 561-2; H. Goldstein, Police Discretion: The Idlal Versus the Real, 23 Puв. Admin. Rev. 140, 143-48; H. Goldstcin, Administrative Problems in Controlling the Exercise of Police Authority, 58 J. Crim. L., C. \& P.S. 160, 169, 171.72 (1967); Challenge, supra note 19, at 103-106; LAFave 61-16t.

Professor LaFave points out that even these financial limitations on law cnforcement, which might be taken as not representing a policy choice on the part of the state, are in fact the legislative body's policy choice as to the general level of law enforcement the community is willing to pay for. Having granted the law enforcement agencies only scarce resources with which to maintain "law and order," the legislature is opting for something less than full enforcement and delegating the policy choices, the sclection of priorities for the limited resources, to the law enforcement agencies.

97. See LAFAve 89-91, 148-9, 155-56.

98. Professor Goldstein has also pointed out that police sometimes use nonenforcenent tactics where relatively serious crimes are involved: narcotics, "victimless" assaults, and rackets violations. J. Goldstein, stpra note 19 , at 562-89. However, uncler the principles of estoppel offered in this Note some of the major examples mentioned would not result in an estoppel defense. For example, in Goldstein's "victimless" assault example the prosecutor refused for a time to prosecute assaults where the victim refused to sign a complaint. Such an enforcement pattern does not create reliance in the citizens subject to it-it least not reliance that the law will not be enforced at all. Rather the citizen, who in all likeli. hood knows that the assault is illegal, knows that the question of prosecution vel non will depend on the victim-and if the victim misleads the defendant as to whether he would prosecute that is not a due process issue since the state is not involved.

99. This is not to make value judgments about the rationality of fully enforcing any substantive criminal statute. It is only to say: (1) that the police do not enforce the latw fully, often pursuant to a conscious policy decision; (2) that the community may not want them to enforce a law fully; and (3) that the community or part thercof, often relies on the nonenforcement policy.

But, the fact that evidence is presented to show that the class of persons of which 
an estoppel defense should be available to the occasional transgressor who relies on the enforcement policy and is prosecuted.

Estoppel by nonenforcement has already gained some small recognition under the heading of desuetude. ${ }^{100}$ Despite some suggestion that desuetude could not be found unless enforcement of a statute had lapsed altogether, the reasons for permitting continuous nonenforcement to serve as a defense press just as strongly when nonenforcement has been only partial. ${ }^{101}$ Nor do sporadic incidents of enforcement preclude estoppel, so long as the nonenforcement remains notorious and the few arrests and prosecutions pass unnoticed by the community. As with estoppel by order and by opinion, the critical element in the nonenforcement estoppel defense is that some agent of the government has caused the defendant to believe that his conduct was not considered outside the law.

Actions, however, can be far more ambiguous in their implications than words, and not every case of selective nonenforcement will justify reliance. If the fact that some crimes were difficult to trace, or that the enforcement agency could not afford to investigate many violations were enough to estop the prosecutor, ${ }^{102}$ most of the criminal law would disappear under the mantle of the estoppel defense. Reliance by pricefixers on the improbability that the Justice Department will discover their activity is hardly justifiable. Passive enforcement tactics-that is, prosecuting an offense only when the evidence is readily availableshould also be insufficient for estoppel, ${ }^{103}$ unless enforcement becomes so passive as to appear almost nonexistent.

the defendant presenting an estoppel defense is a member might have reasonably relied on the enforcement pattern does not excuse the defendant himself from the burden to show that he himself reasonably relied on the selective nonenforcement pattern.

100. See Bonfield, The Abrogation of Penal Statutes by Nonenforcement, 49 Iow. $\mathrm{L}$. REv. 389 (1964).

101. See note 95 supra.

102. If a criminal statute is enforced against all or most of the violations observed by police or enforced randomly, no reliance defense should be upleld cven though the police have adopted an enforcement policy not to investigate for violations of the law which perhaps doesn't catch the largest part of the violations. However, where the enforcement practice is not to arrest for certain types of violations of a law unless for ulterior motives (see note 106 infra; LAFAve 141-152) even when they are observed, the defense should be upheld where reliance is shown.

See Moog Industries, Inc. v. FTC, 255 U.S. 411, 413 (1958) where the Supreme Court upheld the right of the FTC to proceed only against major violators because of inadequate resources for full enforcement:

$[T]$ he commission alone is empowered to develop that enforcement policy best calculated to achieve the ends contemplated by Congress and to allocate its available funds and personnel in such a way as to execute its policy efficiently and cconomically.

A random enforcement policy almost by definition cannot create reasonable reliance of nonenforcement against any person or group within the population governed by the statute. The crux of the problem is in assuring that the enforcement pattern is actually random in something approaching the mathematical use of that term.

103. See note 102 supra. 
As a general rule, there would never be an occasion for estoppel when the pattern of selective nonenforcement appears to reflect something other than an official belief that the purposes of the law did not call for enforcement against certain types of violations. During a riot, for instance, police toleration of looting does not support justifiable reliance because the thief should well know that the general turmoil alone-not official approval of his acts-protects him. ${ }^{104}$ On the same plane, the immunity from arrest and prosecution that racially-motivated crimes often enjoy in some parts of the South has no weight for the purposes of estoppel: there it is not the conduct that the police think unworthy of their attention, but the victims. ${ }^{105}$

Perhaps the strongest case for a defense of estoppel is one in which the occasional arrest and prosecution is based on reasons completely external to the offense itself. ${ }^{108}$ Police may invoke the laws against drunkenness or vagrancy only when they have violators whom they want to harass, interrogate, or simply remove from the streets. ${ }^{107}$ Minor criminal statutes may serve as means of oppressing and intimidating classes of people whom the police dislike. In the latter situation, the estoppel defense can rest equally on due process and equal protection principles. ${ }^{108}$

104. See p. 1070 supra.

105. In different circumstances, perhaps only where very minor offenses are involved, totally illegitimate enforcement criteria (such as race) may give rise to reasonable reliance by that class against whom the statute is not enforced. See, e.g., People v. Harris, 182 Cal. App. 2d Supp. 837, 5 Cal. Rptr. 852 (1960), where a group of blacks were prosecuted under anti-gambling statutes. The defendants offered to prove that there was a police policy of concentrating gambling investigations in black areas, disproportionate prosecutions of blacks relative to the population figures and non-enforcement in instances where police knew that whites were violating the law. The Appellate Department reversed conviction on the ground that the trial court should not have denicd the offer of proof of a clenlal of equal protection of the laws. The case presents a particularly difficult example of the burden of proof that the defendant raising an equal protection defense must bear. Sce Comment, 61 Colum. L. REv. 1103, $1120-1131$ (1961). However, the criminil estoppel defense would be available to white persons able to show reliance on the enforcencut pattern.

106. See, e.g., People v. Walker, I4 N.Y.2d 901, 200 N.E.2d 779, 252 N.Y.S.2d 96 (1961), and 50 Misc. $2 \mathrm{~d} 751,271$ N.Y.S.2d 447 (App. Term, 1st Dept. 1966), reversing the sccond conviction. Defendant Walker demonstrated at the second trial that she was intentionally discriminated against in her prosecution for housing code violations after shc had publicly exposed the corruption in the Department of Buildings in regard to Code cnforcement. In the second decision this was determined to be a denial of equal protection of the laws. However, this might also be an excellent example of the applicability of the crimina! estopple defense where selective nonenforcement has created reliance in certain classes of persons. Defendant Walker was not given the normal amount of time to correct violations in order to avoid prosecution.

107. See LAFAve 149-50. The arresting of a "bad actor" for reasons other than the specific offense involved is one of a number of practices which he discusses under the rubric, "Arrest in Cases in Which the Process is Not Ordinarily Invoked." Id. 144-52. Each presents a separate set of considerations for an estoppel defense.

108. In order to raise a successful equal protection defense to a criminal prosecution under a statute fair on its face, the defendant must show: 1) that the police intentionally 
The development of a full-blown defense of criminal estoppel would bear two interrelated advantages for a rational system of criminal justice. First, the defense would assure a decent standard of fairness for citizens who detrimentally rely on official misrepresentations. Second, it would provide an adequate standard for judicial review of the broad executive discretion granted to the administrators of the criminal law.

discriminated against him or his class; and 2) that the classification made by the police was an unreasonable one in terms of the subject matter of the statute. Comment, The Right to Nondiscriminatory Enforcement of State Penal Laus, 61 Coluar. L. REv. 1103, 1113-1122 (1961). Thus, the defendant must first show somculing more than "inere nonenforcement of the statute against others similarly situated." Dilaggio v. Brown, 19 N.Y.2d 283, 291, 225 N.E.2d 871,279 N.Y.S.2d 161, 167 (1967). Often it is said that the defendant must show "an evil motive causing the statute to be discriminatorily applied." United States v. Elliott, 266 F. Supp. 318, 325 (S.D.N.Y. 1967). Having demonstrated the intentional selectivity or discrimination in enforcement, the defendant inust still show dhat the classification that the police or agency has made is unreasonable, "an unjustifiable standard such as race, religion, or other arbitrary classification." Oyler v. Boles, 368 U.S. 448,456 (1962). A reasonable classification is apparently one that the legislature could have made in the statute itself under the usual "rational connection" test. Sce Kotch $v$. Board of River Port Pilot Com'rs, 330 U.S. 552 (1947); Taylor v. City of Pine Bluff, 266 Ark. 309, 289 S.W.2d 679, cert. denied, 352 U.S. 894 (1956). The following cases are cxamples of successful employment of the defense: People v. Walker, 14 N.Y.2d 901, 200 N.E.2d 779 (1964), 252 N.YS.2d 96; id., 50 Misc. 2d 751, 271 N.Y.S2d 477 (App. Div. 1966). (reversing the second conviction); People v. Harris, 182 Cal. App. 2d Supp. 837, 5 Cal. Rptr. 852 (1960); Bargain City U.S.A., Inc. v. Dilworth, 29 U.S.L.W. 2002 (Phila. City C.P. June 10, 1960), aff'd, $407 \mathrm{~Pa}$. 129, 179 A.2d 439 (1962).

However, criminal estoppel is based on a wholly different rationale than the equal protection defense. Where there are two classes of persons, $A$ and $B$, stubject to the prohibitions of a statute, and $A$ is discriminated against by the police while $B$ las not had the statute enforced against it, defendants in class $A$ will have a valid equal protection defense where the discrimination is intentional and the $\mathrm{A}-\mathrm{B}$ classification is unreasonable. However, defendants in class $B$ who can demonstrate reasonable reliance will always have a criminal estoppel defense whether or not the classification is reasonable (and though they might also be able to raise an equal protection defense in some circumstances; see the Walker case supra). Criminal estoppel goes to the fairness of the notice of illegality that the defendant had in the selective nonenforcement situation, rather than the equal protection clause's mandate of equal justice. 